\title{
Epstein-Barr Nuclear Antigen 1
}

National Cancer Institute

\section{Source}

National Cancer Institute. Epstein-Barr Nuclear Antigen 1. NCI Thesaurus. Code C128296.

Epstein-Barr nuclear antigen 1 (641 aa, 56 kDa) is encoded by the Epstein-Barr virus EBNA1 gene. This protein is involved in the replication of viral DNA during the latent phase. 